\title{
Results of the Quarterly Tritium Survey of Fourmile Branch and its Seeplines in the F and H Areas of SRS: December 1993
}

by

J. Koch (Contact)

Westinghouse Savannah River Company

Savannah River Site

Aiken, South Carolina 29808

V. A. Rogers

K. L. Dixon

B. B. Loonev

This paper was prepared in connection with work done under the above contract number with the U.S. Department of Energy. By acceptance of this paper, the publisher and/or recipient acknowledges the U.S. Government's right to retain a nonexclusive, royalty-free license in and to any copyright covering this paper, along with the right to reproduce and to authorize others to reproduce all or part of the copyrighted paper.

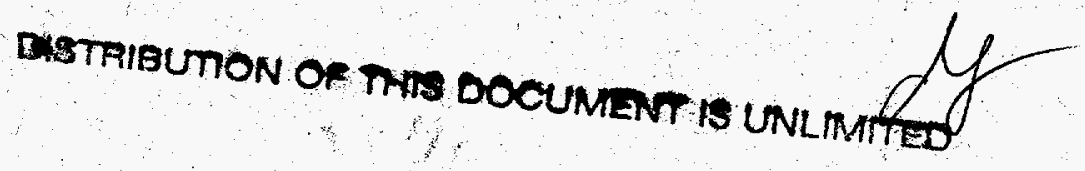




\section{DISCLAIMER}

This report was prepared as an account of work sponsored by an agency of the United States Government. Neither the United States Government nor any agency thereof, nor any of their employees, makes any warranty, express or implied, or assumes any legal liability or responsibility for the accuracy, completeness, or usefulness of any information, apparatus, product, or process disclosed, or represents that its use would not infringe privately owned rights. Reference herein to any specific commercial product, process, or service by trade name, trademark, manufacturer, or otherwise does not necessarily constitute or imply its endorsement, recommendation, or favoring by the United States Government or any agency thereof. The views and opinions of authors expressed herein do not necessarily state or reflect those of the United States Government or any agency thereof.

This report has been reproduced directly from the best available copy.

Available to DOE and DOE contractors from the Office of Scientific and Technical Information, P.O. Box 62, Oak Ridge, TN 37831; prices available from (615) 576-8401.

Available to the public from the National Technical Information Service, U.S. Department of Commerce, 5285 Port Royal Road, Springfield, VA 22161. 


\section{DISCLAIMER}

Portions of this document may be illegible electronic image products. Images are produced from the best available original document. 
WSRC-TR-94-0342

$\operatorname{Rev} 0$

July 1994

\section{Results of the Quarterly Tritium Survey of Fourmile Branch and its Seeplines in the F and H Areas of SRS: December $1993^{(U)}$}

V. A. Rogers, K. L. Dixon, and B. B. Looney

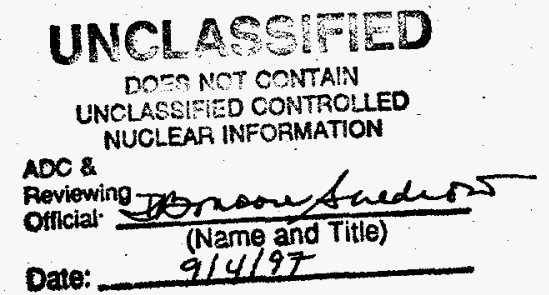

Prepared for the U.S. Department of Energy under contract no. DE-AC09-89SR18035 


\title{
Results of the Quarterly Tritium Survey of Fourmile Branch and its Seeplines in the F and H Areas of SRS: December 1993
}

\author{
V. A. Rogers, K. L. Dixon, and B. B. Looney
}

\section{Abstract}

The Environmental Sciences Section (ESS) of the Savannah River Technology Center (SRTC) established a quarterly monitoring program of the Fourmile Branch (FMB) stream and its associated seepline down gradient from the F- and $\mathrm{H}$ Area seepage basins. The program surveys and tracks changes in tritium, specific conductivity, and $\mathrm{pH}$ for the seepline - water. Measurements from the seventh quarterly survey (December 1993) showed similar to slightly lower tritium and. conductivity measurements and similar $\mathrm{pH}$ values compared to measurements from previous studies. Changes in tritium concentrations and conductivity values, as compared to previous surveys, are attributed to the flushing of tritium from the system and the seasonal rise in the water table since the September 1993 sampling event. Overall results of the tritium survey and related stream monitoring data (Looney, et al., 1993) continue to indicate that the tritium plume that resulted from operation of the seepage basins is flushing from the FMB system.

\section{Executive Summary}

In December 1993 the Environmental Sciences Section (ESS) surveyed the Fourmile Branch (FMB) seepline down gradient from the F- and $\mathrm{H}$-Area seepage basins for tritium, specific conductivity, and $\mathrm{pH}$. The survey was the seventh of ten quarterly surveys for monitoring the movement of contaminants from the basins since closure. Surface-water samples were collected from 60 locations along the seepline and three locations along Fourmile Branch. The seepline locations included 22 from F Area, 22 from $H$ Area, and 16 from the seepline south of $643-E$, which is a decommissioned area in the Solid Waste Disposal Facility. Forty-four of the locations were sampled in 1989 by the Savannah River Technology Center (SRTC) (formerly the Savannah River Laboratory) as part of an extensive characterization study (Haselow et al. 1990). ESS found that tritium activities in F- and H-Area seeplines in December 1993 were significantly lower than the activities measured by Haselow et al. (1990). Tritium increased at a few locations and were attributed to below normal rainfall in the months prior to the September and December 1993 sampling events. The lack of rainfall, which decreased recharge to the shallow groundwater, modified the trajectory of the tritium plume.

The contaminant plume is dynamic and sample point concentration is influenced by seasonal changes in amount and intensity of rainfall, infiltration rate, and vegetative cover. Therefore, the more concentrated area of the plume moves about within the sampling zone at the seepline intercept. This results in changes to tritium concentrations at the seepline intercepts at F-and $\mathrm{H}$-Area seeplines.

Overall, sampling events have consistently shown a declining trend in tritium activity at the $\mathrm{F}$ - and $\mathrm{H}$-Area seepline. Total tritium fluxes to the wetlands and FMB steadily declined since basin closure (Looney et al., 1993) and overall results from the tritium survey support this finding. Differences in tritium activities measured at individual seepline sampling locations from one sampling event to the next represent seasonal variability in depth to the water table, variable amounts of rainfall, as well as changes due to the flushing of the plume from the wetland system. Conclusions about tritium fluxes to the wetlands and FMB should consider the long-term surface water, seepline, and groundwater monitoring data and not rely exclusively on quarterly changes in concentrations at seepline monitoring stations.

December 1993 conductivity measurements exhibited the same general trends as tritium activities in $\mathrm{F}$ and $\mathrm{H}$ Areas. Concentrations of hydrogen ions also decreased in both areas, indicating that conditions are changing from strongly acid $(\mathrm{pH}<4.5)$ to moderately acid $(\mathrm{pH} 5.1-6.0)$, which is near normal for these types of wetlands. Aluminum concentrations measured along the seepline in 1989 
(Haselow et al., 1990) were high enough to be potentially toxic to plants.' Each increase in pH reduces the solubility of aluminum, thereby decreasing the potential for aluminum toxicity to plants. Concentrations of aluminum, as well as other metals, measured along the seepline in July 1992 were substantially lower than 1989 concentrations reflecting the increase in pH (Dixon and Rogers, 1993e). Field observations revealed that vegetation in all areas, except the wetland below location FSP014, is showing noticeable recovery.

The seepline south of 643-E, along a tributary of FMB, is influenced by tritium migrating from the burial grounds. The tributary (old F-Area effluent ditch) is a natural drainage that received effluent discharge from F-Area Separations prior to the construction of the engineered effluent canal. December 1993 tritium activities ranged from 25 to $907 \mathrm{pCi} / \mathrm{mL}$ on the east side of the drainage and from 315 to $36,383 \mathrm{pCi} / \mathrm{mL}$ on the west side. The tritium activity measured in the stream of the natural drainage was 18,738 $\mathrm{pCi} / \mathrm{mL}$. Results suggest that the tritium outcrop area was delineated by the sampling locations established on the - west side of the drainage channel. Conductivity and $\mathrm{pH}$ measurements taken on both sides of the drainage were similar and were within the range of normal values for this type wetland. The low conductivity values measured along the drainage-way suggest that the tritium plume outcropping in the area emanates from 643-E because wastes introduced into 643-E contained low levels of salt ions, compared to the waste in the F- and H-Area seepage basins.

\section{Introduction}

Seepage basins in the $\mathrm{F}$ and $\mathrm{H}$ Areas of SRS received lowlevel radioactive waste effluent from the chemical separation processes in the general separation areas. The basins retained the effluent to slowly release it into the soil. The waste effluent consisted principally of sodium hydroxide, nitric acid, low levels of yarious radionuclides, and some metals (Killian et al., 1985a and 1985b). Discharges of tritiated water to the seepage basins accounted for most of the radioactivity (Fenimore and Horton, 1972).

SRTC conducted an extensive study designed to characterize the shallow groundwater outcropping into FMB and its associated seepline in 1988 and 1989 (Haselow et al., 1990). As a part of this study, Haselow et al. (1990) surveyed for tritium, $\mathrm{pH}$, and conductivity. Researchers found low $\mathrm{pH}$ and elevated conductivity and tritium values along the seeplines and determined that contaminants leaching from the $\mathrm{F}$ - and $\mathrm{H}$-Area seepage basins were impacting the wetlands below the basins. SRS stopped discharges to the seepage basins in 1988 and capped and sealed the basins in 1990 to eliminate the source of contaminants. Scientists hypothesized that after the elimination of the contaminant source, annual rainfall and natural groundwater flow would flush the remaining contaminant plume out of the shallow groundwater over time. After the contaminant plume in the shallow groundwater is flushed out, the impacted wetland systems immediately down gradient from the basins should recover.

To investigate this hypothesis, a quarterly sampling program was established in May 1992. ESS sampled 44 seepline locations sampled by Haselow et al., (1990) for tritium, pH, and specific conductivity. The Haselow et al. (1990) results established the baseline to which the results from the quarterly sampling program are compared. These collection points were chosen as the baseline because they are the only data available that were collected before the basin discharges were discontinued. The Haselow et al. (1990) data should be representative of conditions immediately prior to closing the basins. This sampling program is intended to complement semiannual sampling of the seepline for selected Resource Conservation Recovery Act, Appendix IX characterization, which began in July 1992. A report summarizing results from the semiannual sampling program is complete (Dixon and Rogers, 1993e).

The Environmental Protection Department expressed concern about possible seepage of tritium and other contaminants from an area in the southwest corner of 643-E. To investigate this possibility, numerous sampling locations on the H-Area seepline south of 643-E were established and incorporated into the quarterly sampling plan.

\section{Methods}

ESS conducted the seventh sampling for the quarterly tritium survey in December 1993. Sampling locations were the same as those selected in the sixth round of sampling. This selection, according to 1989 data, exhibited high and low values for the three variables of concern. Attempts were made to establish even ground coverage along both seeplines. ESS. collected 60 samples from the seeplines in $F$ and $H$ Area: 22 from the F-Area seepline, 22 from the $H$-Area seepline, and 16 from the FHB seepline south of 643-E Area. ESS also collected samples from three locations on FMB. Figures 1 and 2 show the sampling locations.

Prior to sampling for the first quarter in May 1992, the Health Protection Department (HPD) collected soil samples from several locations along both seeplines and monitored them for gamma radioactivity. HPD did not detect gamma radiation; therefore, ESS selected rubber boots and disposable rubber gloves as protective clothing to prevent 
dermal contact with seepline water during sampling operations.

Seepline sampling locations were previously marked and labeled with PVC stakes. Samples were collected within a three foot radius of the PVC stake by boring a hole into the soil with a small bucket soil auger, generally six inches and not more than eighteen inches deep to obtain sample. To collect water for tritium analysis, polyethylene sample containers $(25 \mathrm{ml})$ were dipped into the water until full and then capped. The outside of each container was then rinsed with deionized water and sealed in a small polyethylene bag to minimize the possibility of contamination. The small bags were then sealed in a large polyethylene bag. The Environmental Monitoring Section (EMS) performed tritium analysis (total activity). EMS counted $5 \mathrm{ml}$ aliquots for $\mathbf{2 0}$ minutes, which yielded a lower detection limit of $1.3 \mathrm{pCi} / \mathrm{mL}$ (WSRC-3Q1-4, 1992).

ESS measured specific conductivity and $\mathrm{pH}$ in situ with conductivity and $\mathrm{pH}$ electrodes (WSRC-L14.1, 1992a and 1992b). The electrodes were rinsed with deionized water

$\because \quad$ after each sampling. All sampling equipment was thoroughly rinsed with deionized water at the end of each day.

\section{Results and Observations}

Concentrations of variables measured at seepline sampling locations fluctuate throughout the year. Climatic and seasonal conditions, especially rainfall amounts, influence measured concentrations. Seepline measurements are made on water collected from fixed locations at the distal end, or toe, of the contaminant plume. Because the plume is dynamic (i.e., influenced by weather and other activities in the area) seepline monitoring is sensitive to long-term changes and seasonal/transient infiuences. Groundwater flow paths in F- and H-Area are complex, as illustrated in Figure 3 and 4 . Recharge to the groundwater is primarily due to infiltration of rainwater (rainfall minus runoff and evapotranspiration). Groundwater then moves laterally to. FMB and its tributaries.

As the water travels toward the stream, additional infiltration forces up-gradient water deeper. Near the stream, the flow lines rise to the surface, emerging between the seepline and the stream (which acts as the groundwater "drain"): This classic vertical trajectory, a path curving downward near the groundwater divide and then upward into draining surface water, is shown as flow lines on Figures 3 and 4 .

Figure 3 shows the flow lines without contaminated water from the seepage basins and Figure 4 shows the addition of contaminated flow lines from the basins when they were receiving water. The theoretical plume geometry is clearly confirmed by the real vertical profile of the F-Area seepage basin plume based on the detailed grid wells available in the 1970s (Looney et al.; 1993). Changes in the water balance in the area influence the flow velocity and tend to move the plume either deeper or shallower and cause the location of the contaminated water to move. This is especially important to data interpretation if the "toe" of the plume is shifting relative to the fixed sample stations. Figure 5 summarizes the expected changes in the plume based on a range of transient activities. Increased rainfall (or other activities that increase infiltration such as harvesting trees) results in increased plume velocity and movement of the plume downward and away from the seepline. This results in decreased contaminant concentrations as measured at the seepline sampling locations. Reduction in infiltration results in decreased plume velocity and movement of the plume center upward and closer to the seepline. This results in increased contaminant concentrations as measured at the seepline sampling locations.

Low rainfall for a few months prior to sampling results in increased constituent concentrations, and high rainfall results in decreased constituent concentrations in the shallow groundwater at the seepline intercept. Rainfall measured at SRS at the weather station in F-Area from January through November 1993 was $120 \mathrm{~cm}$. From 1960 to 1991, the average rainfall measured in $F$ Area from the month of January through November was $123 \mathrm{~cm}$. This indicates that average rainfall in $\mathrm{F}$ and $\mathrm{H}$ Areas was near normal for the period; however, about 50 percent of the rainfall occurred in the first three months of the year.

Figure 6 shows a comparison of 1993 rainfall to the longterm average (1960-1991) for the period January through November. This figure shows that except for June and September, rainfall was close to the long-term average. Rainfall totals for June and September were heavily influenced by brief, intense storms. Storms of this nature commonly yield large amounts of rainfall over short periods of time with high runoff and low infiltration. This type of event would not be expected to ameliorate the effects of six months of below average rainfall.

The below average rainfall observed in the area prior to the September 1993 sampling event, continued through October and November. The contaminant concentrations increased at some sampling locations. A $3.94 \mathrm{~cm}$ rainfall event was recorded ten days prior to the sampling event. In sandy areas this was sufficient time for the water to reach the seepline. An increase in rainfall along with seasonal change was sufficient to lower the concentrations at a few sample locations. 
Figures 7 through 12 show comparisons of March 1989 with September and December 1993 tritium, conductivity, and $\mathrm{pH}$ measurements for locations in $\mathrm{F}$ and H-Area seepline. Data for the first six surveys can be found in Dixon and Rogers (1992, 1993a, 1993b, 1993c, 1993d, and Dixon et al., 1994). Figures 13 through 18 show the data for the FMB locations and the seepline south of 643$\mathrm{E}$ in $\mathrm{H}$ Area. They were identified with the prefix FHB.

\section{$F$ and $H$-Area Seepline Tritium Measurements}

\section{F Area}

December 1993 tritium values in the F-Area seepline ranged from 13 to $10436 \mathrm{pCi} / \mathrm{mL}$ (see Figure 7 and Table 2). Three of the 22 sampling locations had above-background tritium activities that exceeded the 1989 measurements by more than $10 \%$. Two of the three sample locations are adjacent to the floodplain of FMB and subject to stream flooding. The third sample location is close to the slope of a drainageway and therefore, subject to extreme sample variation. In 1989, maximum tritium activities - $(14,000 \mathrm{pCi} / \mathrm{mL})$ were measured at FSP014 and FSP034 sample locations.

As with data from previous quarters, a Wilcoxon signedrank test was conducted to compare December 1993 tritium activities to March 1989 activities. The Wilcoxon signed-rank test uses the sign and the magnitude of the rank of the differences between pairs of measurements to compare nonparametric data (Daniel, 1978). This test was chosen because it allows comparisons of paired data without assumptions of normality. The results showed that the December 1993 concentrations were significantly less $(P=0.009)$ than the 1989 concentrations.

\section{H Area}

Tritium values in the H-Area seepline ranged from 116 to $12688 \mathrm{pCi} / \mathrm{mL}$ (Figure 8 and Table 3). Of the 22 sampling locations, four had above-background tritium activities that exceeded the 1989 measurements by more than $10 \%$. No tritium activity exceeded the maximum value of $24,000 \mathrm{pCi} / \mathrm{mL}$ measured in 1989 and three of the four locations showing an increase were influenced by the floodplain rather than only seepage from the uplands, therefore inducing greater variability. The one sample location close to the basins with an increase was only by $250 \mathrm{pCi} / \mathrm{mL}$ This magnitude of change was likely due to sampling variation.

As with data from F Area, a Wilcoxon signed-rank test was conducted to compare December 1993 tritium activities to March 1989 activities. The results showed that the December 1993 concentrations were significantly less $(P=0.0009)$ than the 1989 concentrations for $H$ Area. Even though tritium activities increased at several locations compared to previous sampling events, they remained substantially lower than those measured in 1989 at most locations.

Figures 7 and 8 show tritium activity at $F$ and $H$ Area for the December 1993 sampling event, to decrease at 23 sample locations while 16 increased and five locations remained relatively unchanged compared to previous sampling events. These results, for the most part, track rainfall and seasonal change. Previous sampling events consistently showed a declining trend in tritium concentrations at the F-and H-Area seeplines. For six months prior to the December 1993 sampling event, the below average rainfall caused the plume to shift in the direction of FMB causing higher concentrations nearer FMB and lower concentrations close to the basins.

When rainfall returns to normal amounts, the plume should move deeper in the soil profile. This trend is noted in the December data. It is important to understand that total tritium fluxes to the wetlands and FMB steadily declined since basin closure (Looney et al., 1993) and that overall results of the tritium survey support this finding. Differences in tritium concentrations measured at seepline sampling locations from one sampling event to the next represent seasonal variability, variable rainfall as well as changes due to the flushing of the plume from the wetland system. Conclusions about tritium fluxes to the wetlands and FMB should consider the complexity of the groundwater system and should be based on long-term surface water, seepline, and groundwater monitoring data and not on quarterly changes in concentrations at seepline monitoring locations.

\section{F- and $\mathrm{H}$-Area Seepline Conductivity Measurements}

\section{F Area}

Conductivity measurements in the F-Area seepline ranged from 27 to $1650 \mathrm{mS} / \mathrm{cm}$ (Figure 9 and Table 2). Due to the variability of conductivity measurements, only differences of $100 \mathrm{mS} / \mathrm{cm}$ or more are considered significant. Of the 22 locations sampled at the F-Area seepline, two had measurements of more than $100 \mathrm{mS} / \mathrm{cm}$ above the 1989 measurements. A comparison of the graphs in Figures 7 and 9 suggests that conductivity follows the same general trends as the tritium activities. Using a Spearman rank correlation test for nonparametric data, it was found that the 
probability that tritium and conductivity exhibited independent trends $(P<0.001)$. The rank correlation coefficient was found to be $r s=0.95$, suggesting that the two parameters exhibit the same trends. This similarity is expected because tritium serves to track the movement of the contaminant plume from the basins (Haselow et al., 1990).

\section{H Area}

Conductivity measurements in the H-Area seepline ranged from 52 to $612 \mathrm{mS} / \mathrm{cm}$ (Figure 10 and Table 3). Of the 22 sampling locations, one had a measurement of more than $100 \mathrm{mS} / \mathrm{cm}$ above the 1989 measurements. Data in Figures 8 and 10 suggest that conductivity and tritium are following the same general trends. The Spearman rank correlation test for nonparametric data was used to investigate the correlation of $\mathbf{H}$. Area tritium activities and conductivity values. Probability that the two parameters exhibited independent trends was $\mathbf{P}<0.001$. The rank correlation coefficient ( $r=0.87$ ) for $\mathrm{H}$ Area was lower than that for F Area, but still suggested a good correlation.

\section{$\because \quad F$ - and $\mathrm{H}$-Area Seepline $\mathrm{pH}$ Measurements}

$\mathrm{F}$ Area $\mathrm{pH}$ values ranged from 3.7 to 6.3 with an average value of 5:1 (Figure 11 and Table 2). H Area $\mathrm{pH}$ values ranged from 4.8 to 6.4 with an average of 5.6 (Figure 12 and Table 3). The $\mathrm{pH}$ for the entire seepline ( $\mathrm{F}$ and $\mathrm{H}$ Areas combined) averaged 5.4. The average increased 0.5 units over the 4.9 average in 1989 (Haselow et al., 1990). In each of the past six surveys, the hydrogen ion concentration decreased threefold compared to 1989 measurements. The increase in $\mathrm{pH}$ will affect the solubility of metals in the soil, which should improve the soil water chemistry and enhance the recovery of wetland vegetation stressed indirectly by low $\mathrm{pH}$. Aluminum concentrations measured along the seepline in 1989 (Haselow et al., 1990) were high enough to be toxic to plants. Increases in $\mathrm{pH}$ from and average of 4.9 in 1989 to 5.4 reduced the amount of aluminum in solution and thereby reduce it as a possible source of plant toxicity. Concentrations of aluminum and other metals measured along the seepline in July 1992 were substantially lower than 1989 concentrations, reflecting the increase in pH (Dixon and Rogers, 1993e). Field observations revealed that vegetation in the stressed areas, except the wetland south of FSP014 sample location, is making noticeable recovery:

\section{Fourmile Branch Measurements}

Figures 13 through 15 show the tritium, conductivity, and $\mathrm{pH}$ values for the FMB sampling locations. Table 4 provides the data used in the figures. Tritium activities at these locations ranged from 37 to $567 \mathrm{pCi} / \mathrm{mL}$. These values were consistent with previous data and show increases in tritium down stream as the seepline water enters the channel of Fourmile Branch. Conductivity measurements ranged from 74 to $91 \mathrm{mS} / \mathrm{cm}$ and $\mathrm{pH}$ ranged from 6.1 to 6.5 . The conductivity and $\mathrm{pH}$ values were at near normal levels.

\section{Solid Waste Disposal Facility (643-E) Seepline Measurements}

The graphs in Figures 16 through 18 show tritium, conductivity, and $\mathrm{pH}$ values for the seepline and stream sampling locations south of 643-E, which is part of the Solid Waste Disposal Facility. Sample points on the east side of the drain were established in December 1992 and the sample locations on the west side were added in March 1993. Table 5 provides the data used in the figures. This seepline is along the natural drainage (old F-Area effluent ditch) that was used to discharge effluent from F-Area separations prior to the construction of the engineered effluent canal.

Tritium activities for the locations on the east side of the drainage ranged from 25 to $907 \mathrm{pCi} / \mathrm{mL}$. Activities on the west side of the drainage ranged from 91 to $36,383 \mathrm{pCi} /$ $\mathrm{mL}$. The tritium activity in the stream at location (FHB012) was $18,738 \mathrm{pCi} / \mathrm{mL}$. This represents a convergence of the contaminant plume with relatively clean water from the seepline on the east slope of this drainage system.

Conductivity measurements on both sides of the drainage were near background at most locations and ranged from 27 to $428 \mu \mathrm{S} / \mathrm{cm}$. Some locations exhibited elevated conductivity values; however, these values are typical of the conductivity values typically reported in the water table wells in the vicinity of the old F-Area effluent ditch (EMS, 1993). Using the Spearman rank correlation test, no correlation ( $r s=-0.03$ ) was found between conductivity and tritium for these locations. $\mathrm{pH}$ values ranged from 4.1 to 5.8 , with an average of 5.0.

These results are consistent with the Haselow et al. (1990) results for the western portion of the H-Area seepline, particularly near location HSP103. Haselow et al. (1990) found that down gradient from 643-E, conductivity values were near background while tritium concentrations were elevated. This was attributed to tritiated wastes deposited in 643-E. Tritium activities measured along the seepline down gradient of 643-E (particularly sample points on the west side) suggest that tritium migrating from $643-\mathrm{E}$ and outcropping in this area is substantial. The appearance of tritium on the west side as opposed to the east side of the 
drainage suggests that soil material placed in the northern reaches of the natural drainage is forcing the tritium plume to outcrop down gradient. It appears that the groundwater and tritium are moving below the fill material and outcropping on the west side of the drainage. The results suggest that the sampling locations on the west side of the drainage delineated the tritium plume with the center located at or near FHB018.

\section{Conclusions}

Tritium concentrations measured at most locations in December 1993 decreased or remained relatively unchanged compared to previous sampling events. These results vary only slightly from previous sampling events and are attributed to the dynamic nature of the tritium plume movement. Below-normal rainfall for the past six months caused the toe of the tritium plume to migrate toward the seepline intercept and away from FMB. As rainfall returns to normal and the winter season begins, the plume is expected to show higher tritium concentrations closer to the basins. Total tritium fluxes to the wetlands -and FMB steadily declined since basin closure (Looney et al., 1993) and overall results from the tritium survey support this finding.

These data support the hypothesis that the tritium plume in $F$ and $H$ Areas is being flushed from the shallow groundwater. Differences in tritium concentrations measured at seepline sampling locations from one sampling event to the next represent seasonal changes in the amount and the intensity of rainfall, infiltration rate, and vegetative cover, as well as changes due to flushing of the contaminant plume from the wetland system. No correction has been made for normal tritium decay because of the short time between sample events. Conclusions about tritium fluxes to the wetlands and FMB should consider the complexity of the groundwater system and should be based on longterm surface water, seepline, and groundwater monitoring data and not on quarterly changes in concentrations at seepline monitoring locations.

Evaluation of data from 16 seepline locations south of the 643-E Area indicates that tritium migrating from $643-E$ is outcropping along the old F-Area effluent ditch, particularly on the west side of the channel. It appears that sampling locations on the west side of the channel delineated the tritium plume outcrop area as driven by the present climatic and hydrologic conditions.

\section{References}

Daniel, W. W. 1978. Applied Nonparametric Statistics. Houghton Mifflin Company, Boston, MA.

Dixon, K. L. and V. A. Rogers. 1992. Results of the First Quarter Tritium Survey of the F- and H-Area Seeplines: May 1992. WSRC-TR-92-304, Westinghouse Savannah River Company, Savannah River Technology Center, Aiken, SC.

Dixon, K. L. and V. A. Rogers. 1993a. Results of the Second Quarter Tritium Survey of the F- and H-Area Seeplines: September 1992. WSRC-TR-93-129, Westinghouse Savannah River Company, Savannah River Technology Center, Aiken, SC.

Dixon, K. L. and V. A. Rogers. 1993b. Results of the Third Quarter Tritium Survey of the F- and $H$-Area Seeplines: December 1992. WSRC-TR-93-284, Westinghouse Savannah River Company, Savannah River Technology Center, Aiken, SC.

Dixon, K. L. and V. A. Rogers., 1993c. Results of the Fourth Quarter Tritium Survey of the F-and H-Area Seeplines: March/April 1993. WSRC-TR-93-526, Westinghouse Savannah River Company, Savannah River Technology Center, Aiken, SC.

Dixon, K. L. and V. A. Rogers. 1993d. Results of the Quarterly Tritium Survey of Fourmile Branch and its Seeplines in the F-and H-Areas of SRS: June 1993. WSRC-TR-93-656, Westinghouse Savannah River Company, Savannah River Technology Center, Aiken, SC.

Dixon, K. L. and V. A. Rogers. 1993e. Semi-Annual Sampling of Fourmile Branch and Its Seeplines in the $F$ and $H$ Areas of SRS: July 1992. WSRC-TR-93-289, Westinghouse Savannah River Company, Savannah River Technology Center, Aiken, SC.

Dixon, K. L., V. A. Rogers, and B. B. Looney. 1994. Results of the Quarterly Tritium Survey of Fourmile Branch and Its Seeplines in the F and H Areas of SRS: September 1993. WSRC-TR-94-0286. Westinghouse Savannah River Company, Savannah River Technology Center, Aiken, SC.

Environmental Monitoring Section (EMS): 1993. The Savannah River Site's Groundwater Monitoring Program, Second Quarter Report. ESH-EMS-930097, Westinghouse Savannah River Company, Aiken SC.

Fenimore, J. W. and J. H. Horton. 1972. Rating History and Environmental Effects of Seepage. Basins in Chemical Separations Areas of the Savannah River Plant. DPST-72-548, E. I. du Pont de Nemours and Company, Savannah River Laboratory, Aiken, SC. 
Haselow, J. S., M. Harris, B. B. Looney, N. V. Halverson, and J. B. Gladden. 1990. Analysis of Soil and Water at the Fourmile Branch Seepline Near the $F$ and $H$ Area of SRS (U). WSRC-RP-90-0591, WSRC-TR-92-304, Westinghouse Savannah River Company, Savannah River Technology Center, Aiken, SC.

Killian, T. H., N. L. Kolb, P. Corbo, and I. W. Marine. 1985a.F-Area Seepage Basins. DPST-85-704, E. I. du Pont de Nemours and Company, Savannah River Laboratory, Aiken, SC.

Killian, T. H., N. L. Kolb, P. Corbo, and I. W. Marine. 1985b. H-Area Seepage Basins. DPST-85-706, E. I. du Pont de Nemours and Company, Savannah River Laboratory, Aiken, SC.
Looney, B. B., J. S. Haselow, C. M. Lewis, M. K. Harris, D. E. Wyatt, C. S. Hetrick. 1993. Projected Tritium Releases from $F$ and $H$ Area Seepage Basins and the Solid Waste Disposal Facilities to Fourmile Branch (U). WSRC-RP-93-459, Westinghouse Savannah River Company, Savannah River Technology Center, Aiken, SC.

WSRC-3Q1-4. 1992. Determination of Tritium in Water. Procedure 2760, Rev 0. Westinghouse Savannah River Company, Aiken, SC.

WSRC-L14.1. 1992a. Procedure for Cole-Parmer Portable Conductivity Meter Model 1481-40. Procedure. 2-79, Rev 1. Westinghouse Savannah River Company, Aiken, SC.

WSRC-L14.1. 1992b. Procedure for Cole-Parmer Model 5985-80 pH Meter. Procedure 2-81, Rev 1. Westinghouse Savannah River Company, Aiken, SC. 


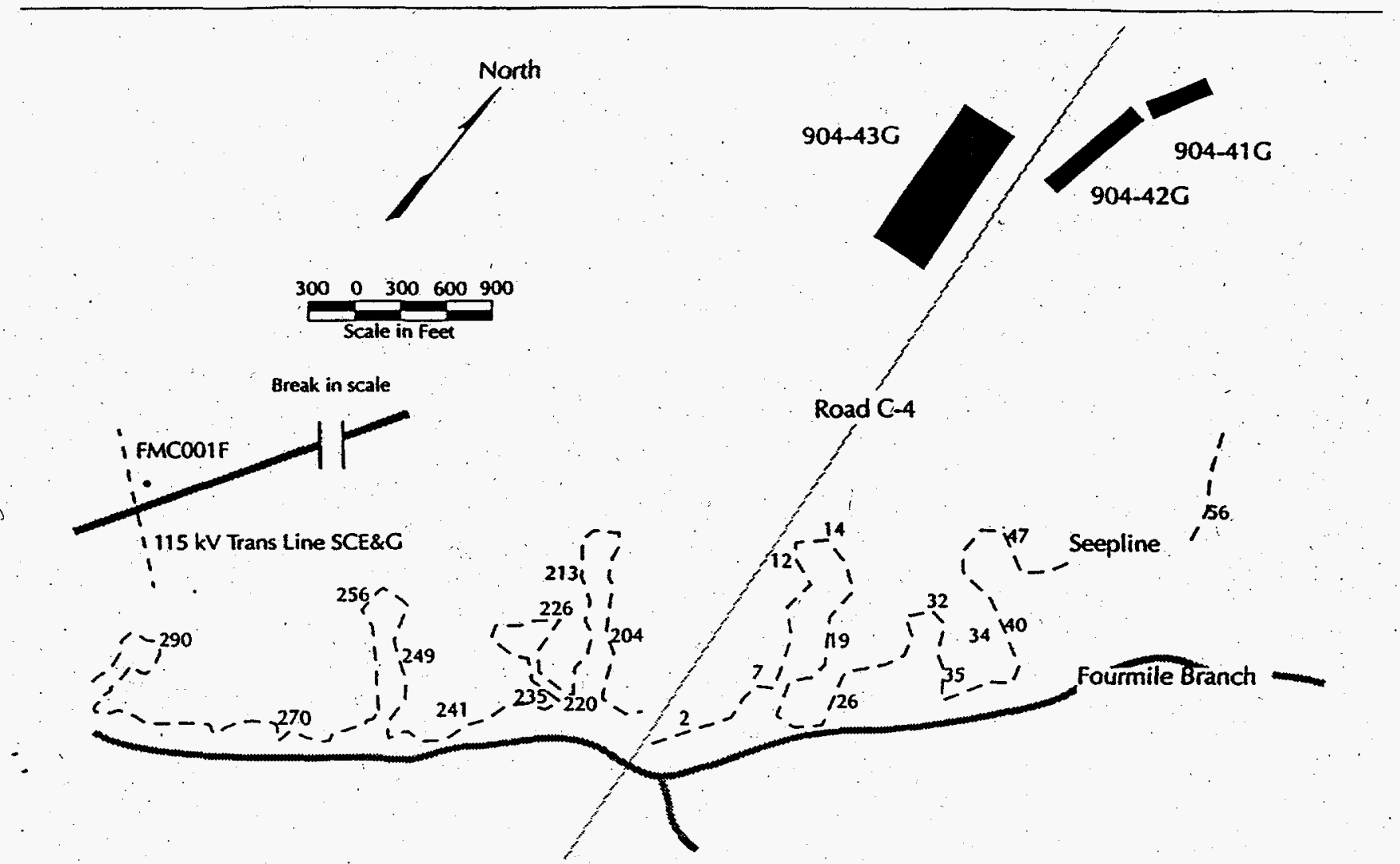

Figure 1. Location of F-Area Seepage Basins Relative to Seepline and Stream Sample Sites.

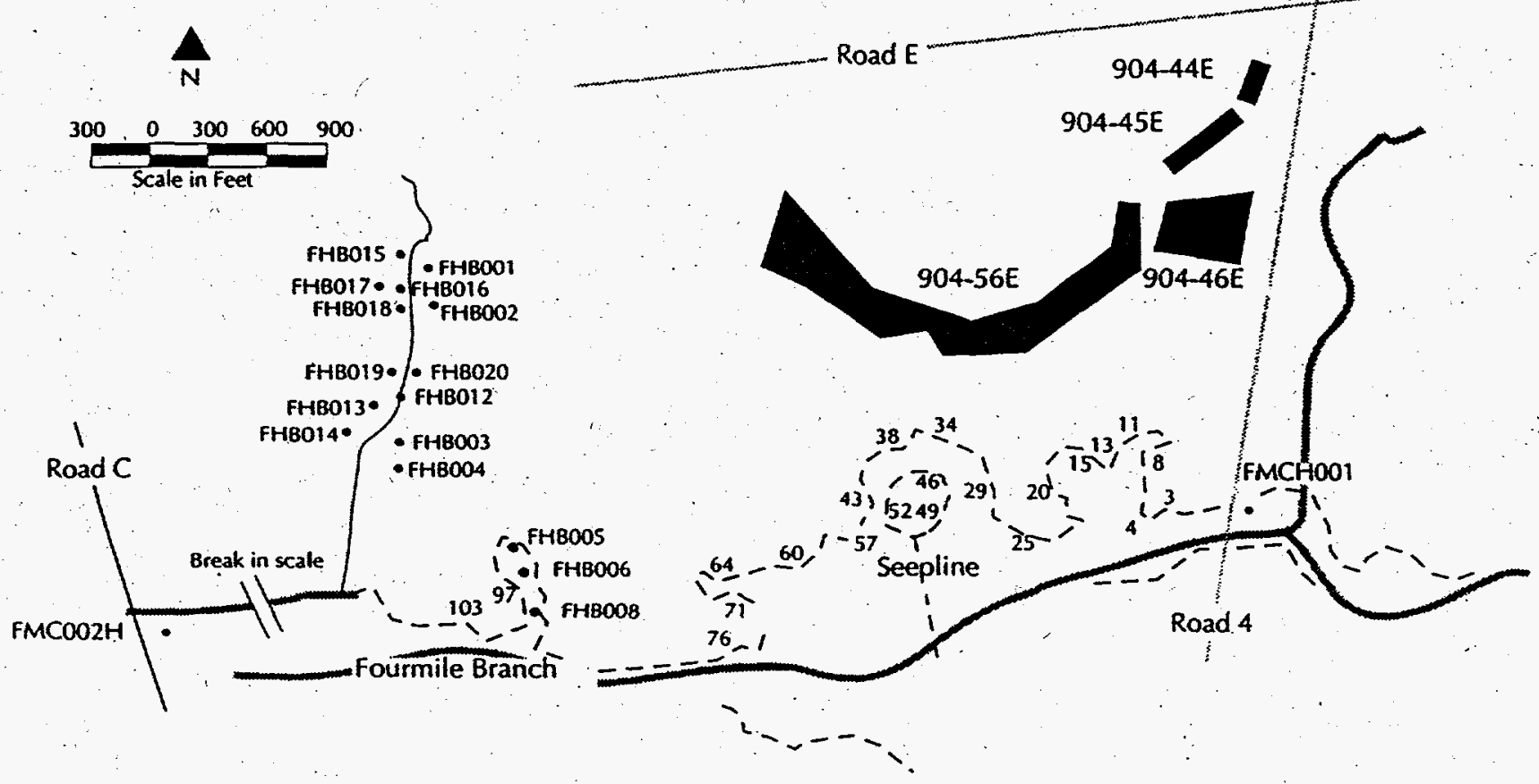

Figure 2. Location of H-Area Seepage Basins Relative to Seepline and Stream Sample Sites. 


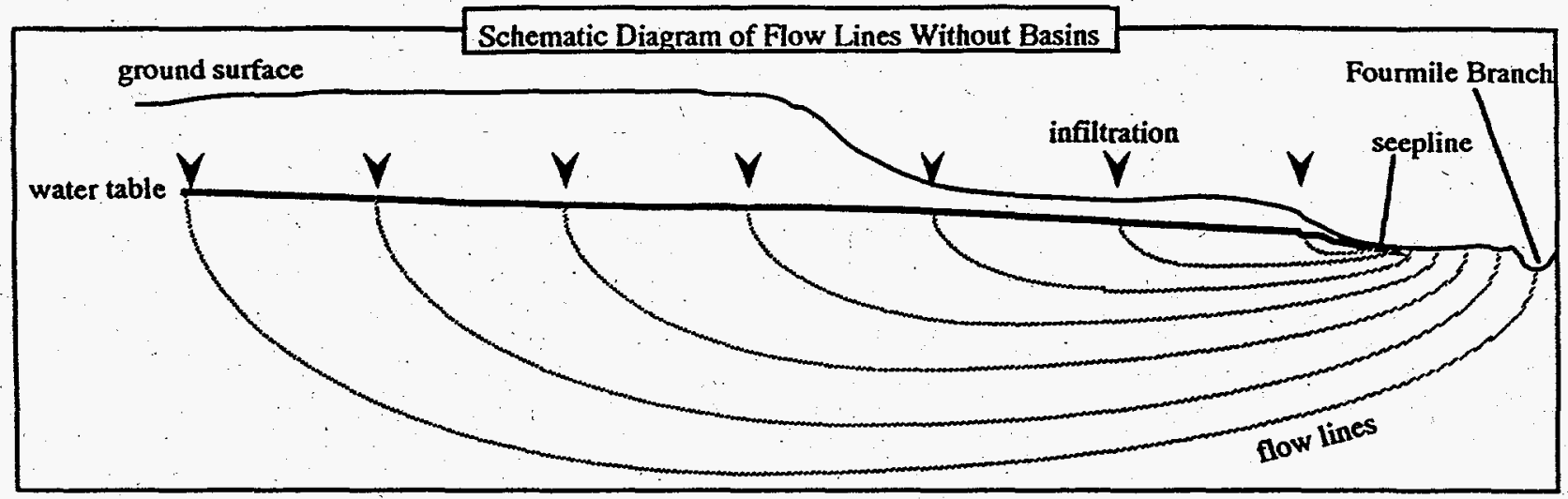

Figure 3. Schematic Diagram of Flow Lines in the Shallow Groundwater at the F- and H-Area without Seepage Basins.

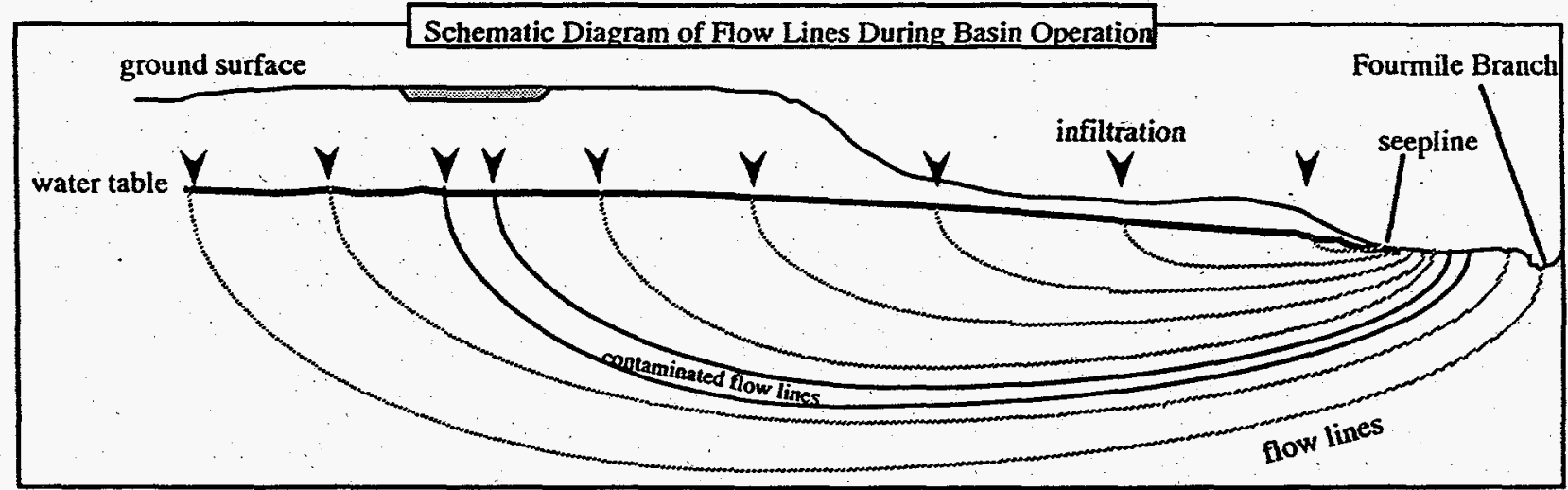

Figure 4. Schematic Diagram of Flow Lines in the Shallow Groundwater at the F-and H-Area Seepline During Basin Operation. 


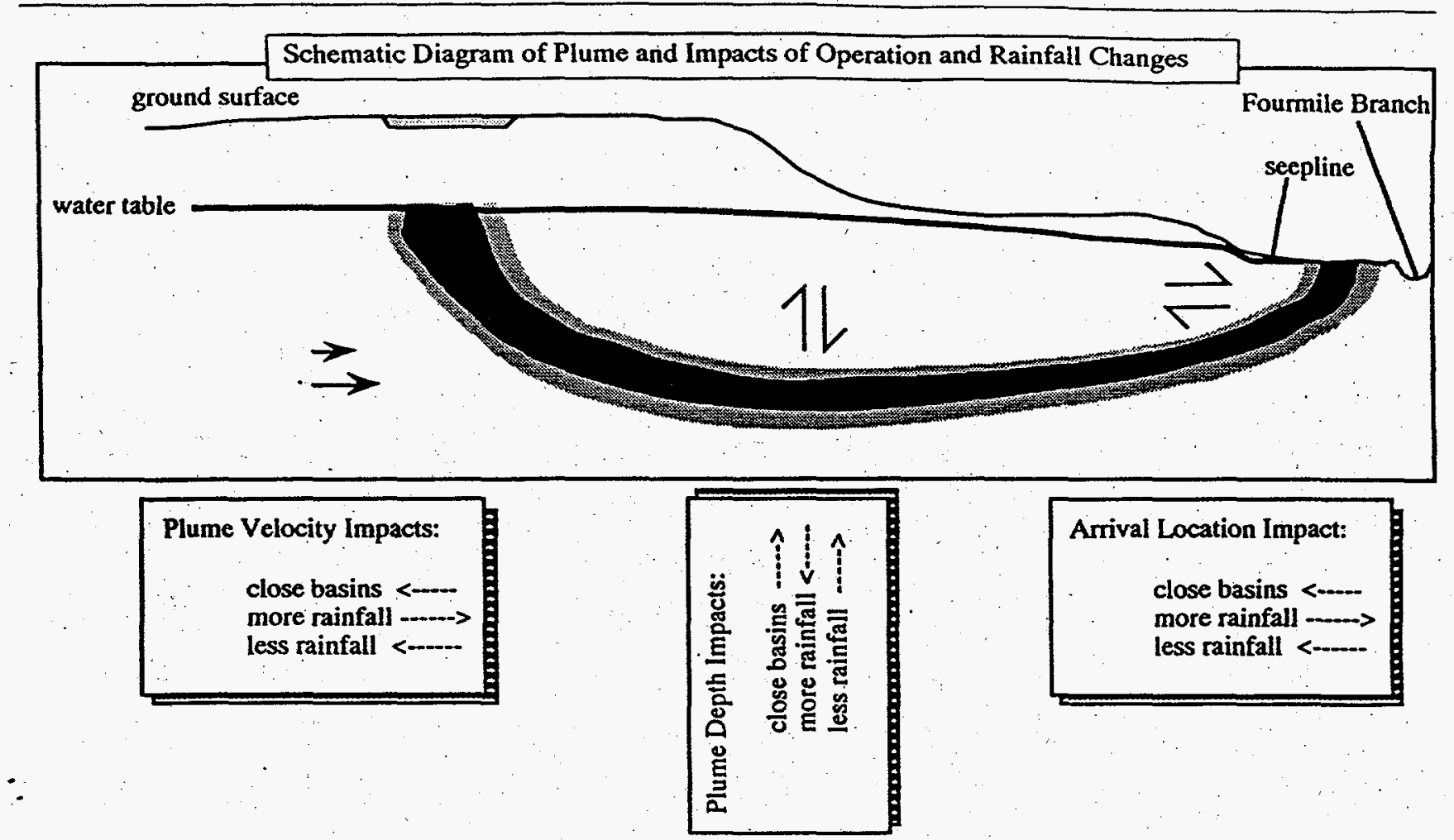

Figure 5. Schematic Diagram of the Tritium Plume Migrating from F- and H-Area Seepage Basins.

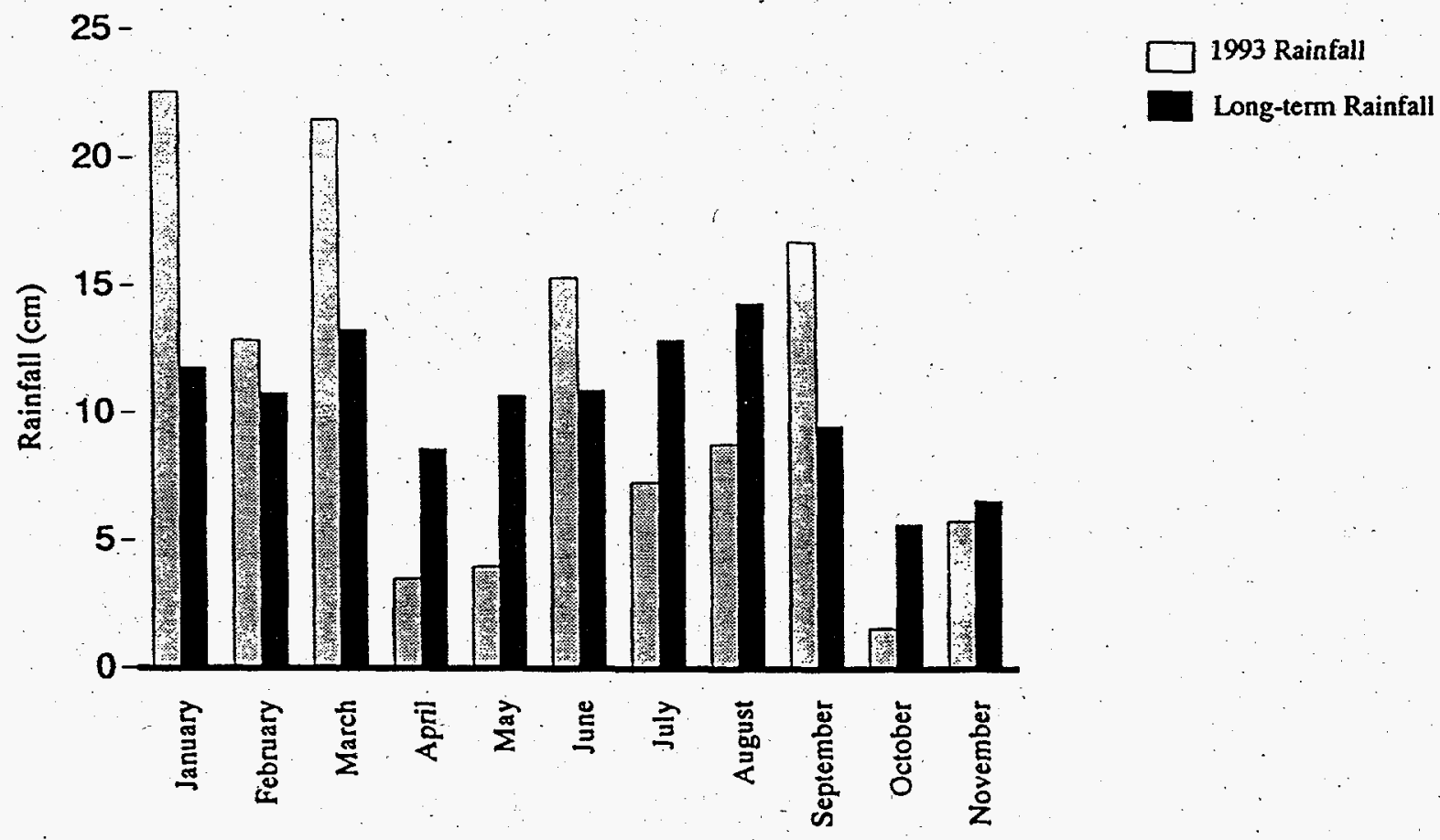

Figure 6. Comparison of 1993 Rainfall Totals (January-November 1993) to the Long-Term Average (1960-1991) for F-Area Weather Station. 


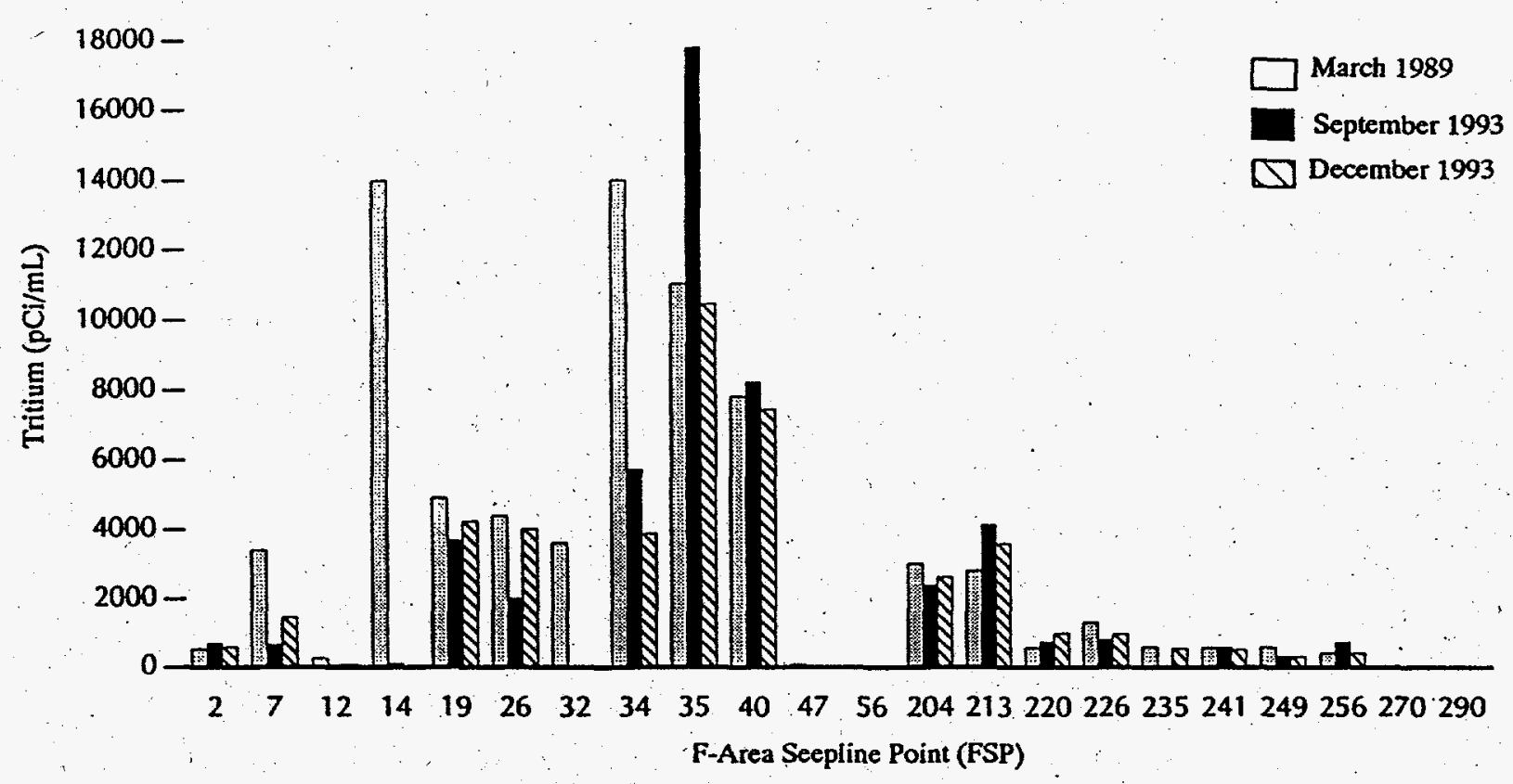

- Figure 7. Comparison of March 1989 and September and December 1993 Tritium Concentrations for Selected F-Area Seepline Locations.

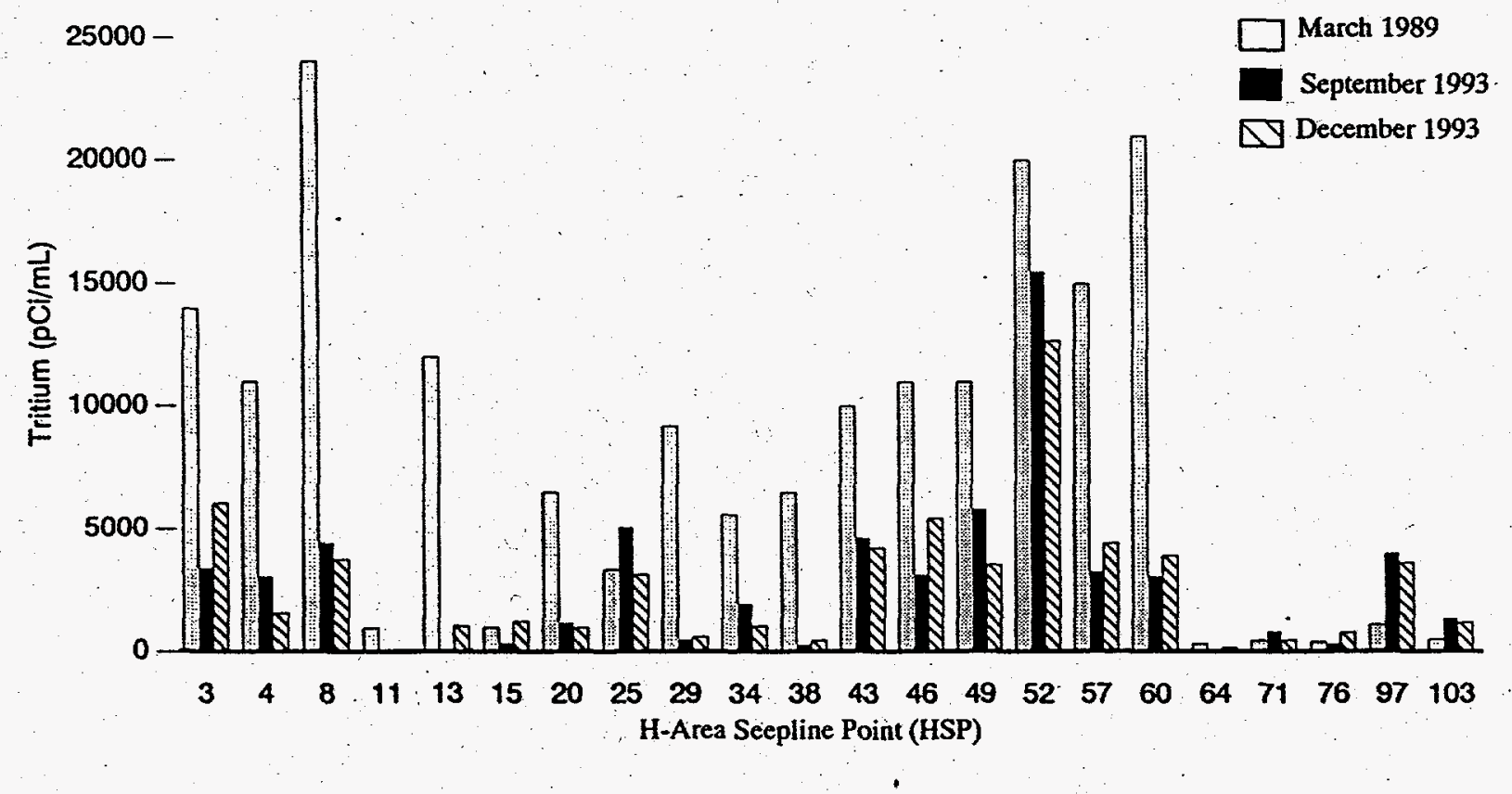

Figure 8. Comparison of March 1989 and September and December 1993 Tritium Measurements for Selected H-Area Seepline Locations. 


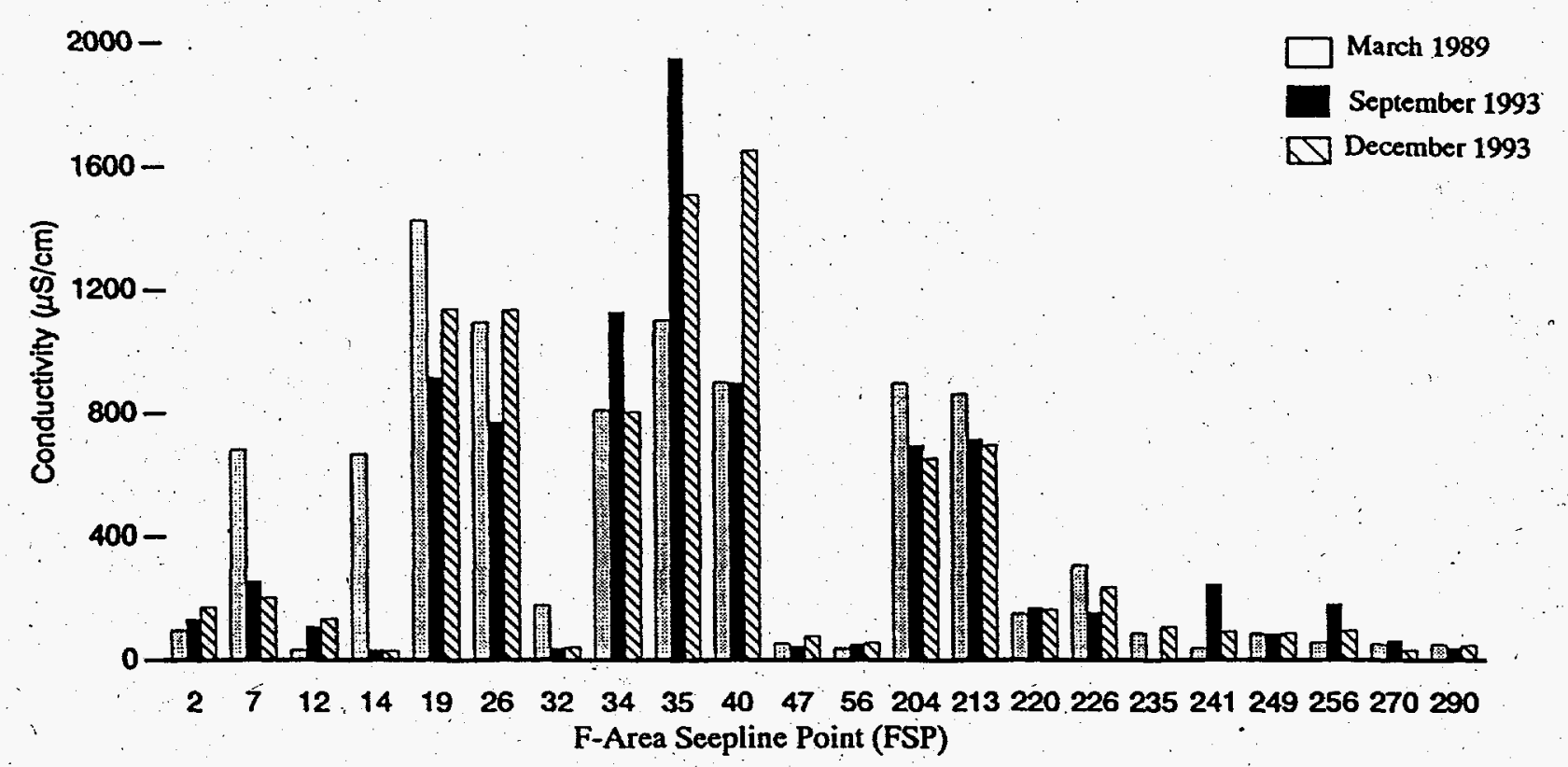

Figure 9. Comparison of March 1989 and September and December 1993 Conductivity Measurements for Selected F-Area Seepline Locations.

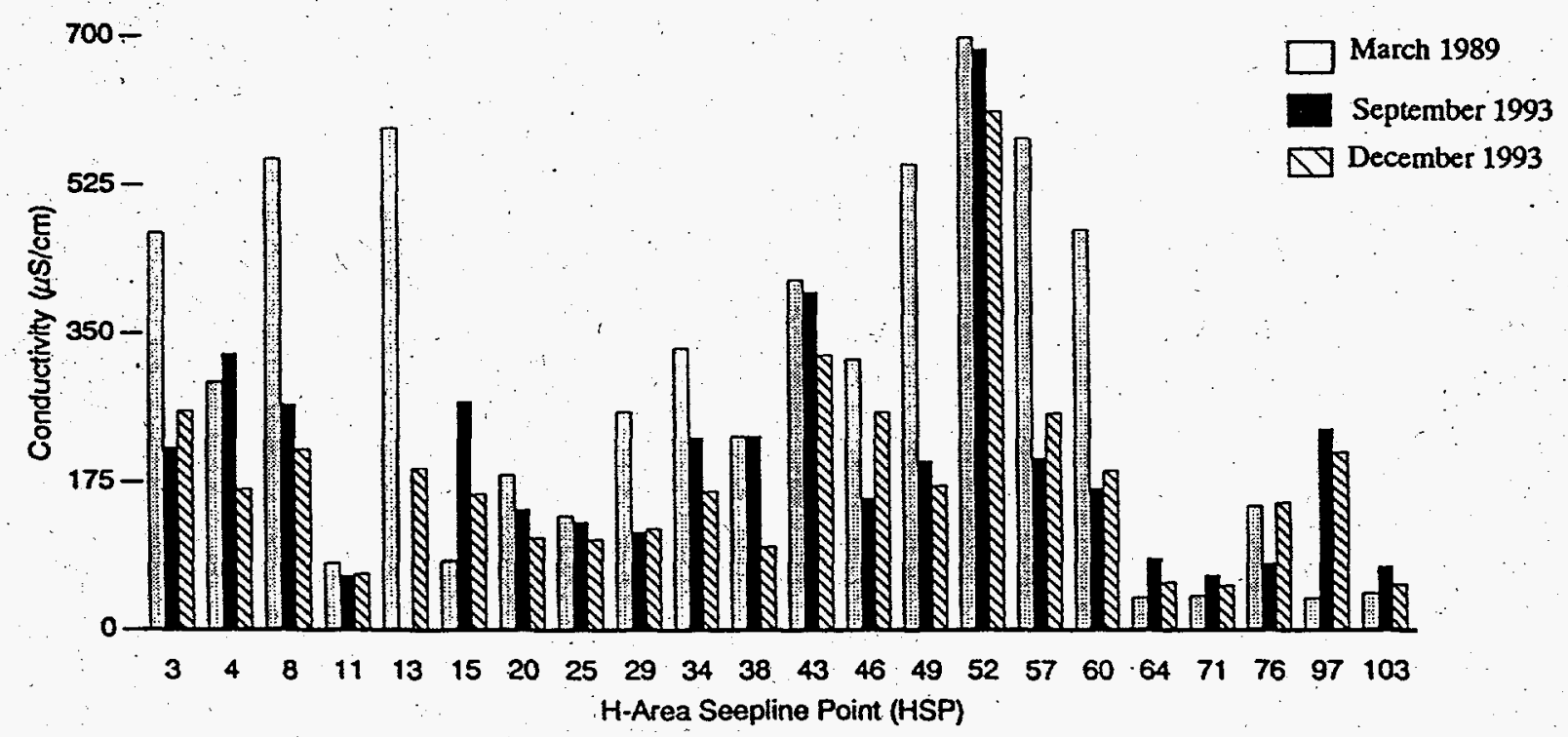

Figure 10. Comparison of March 1989 and September and December 1993 Conductivity Measurements for Selected H-Area Seepline Locations. 


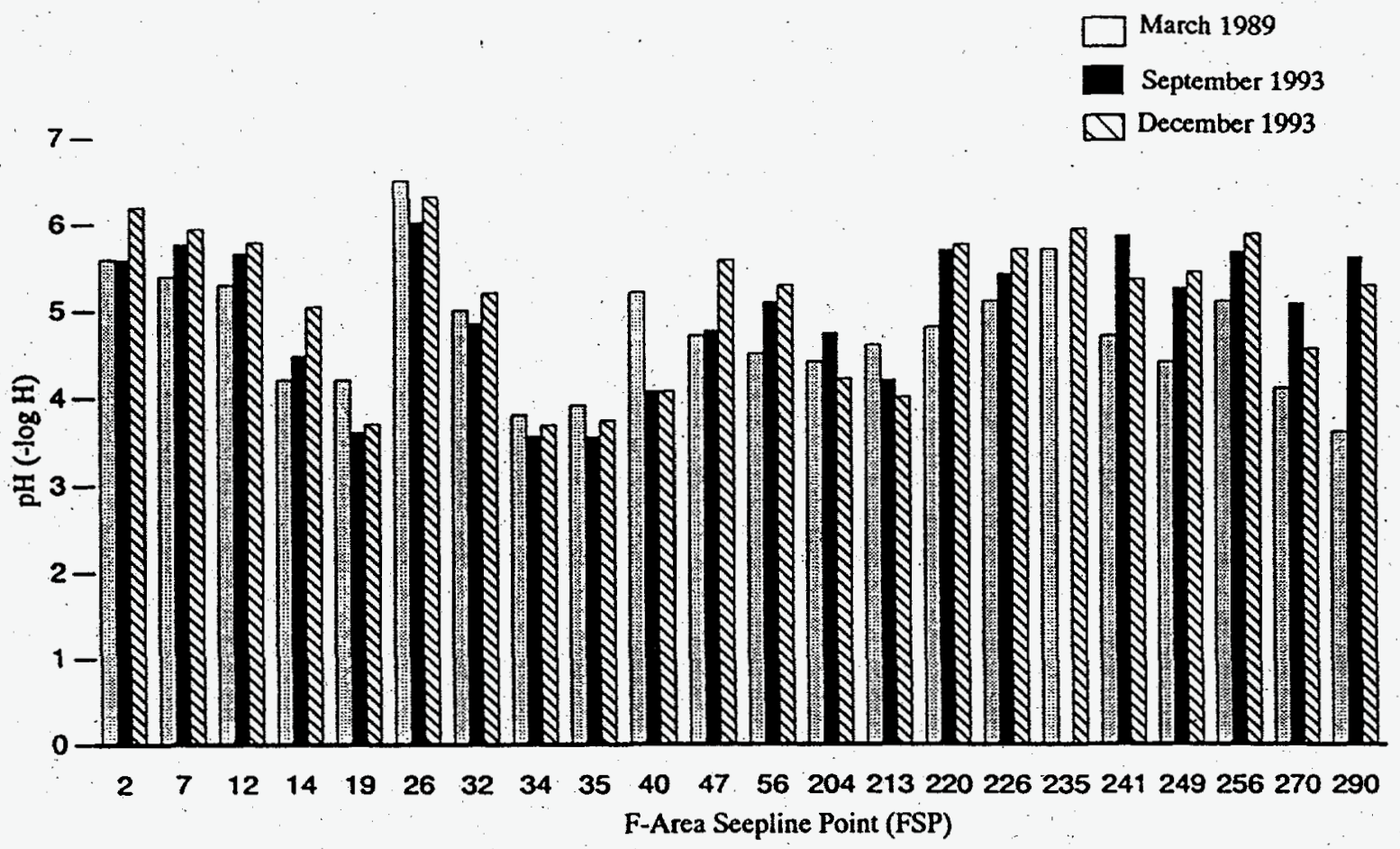

Figure 11. Comparison of March 1989 and September and December $1993 \mathrm{pH}$ Measurements for Selected F-Area Seepline Locations.

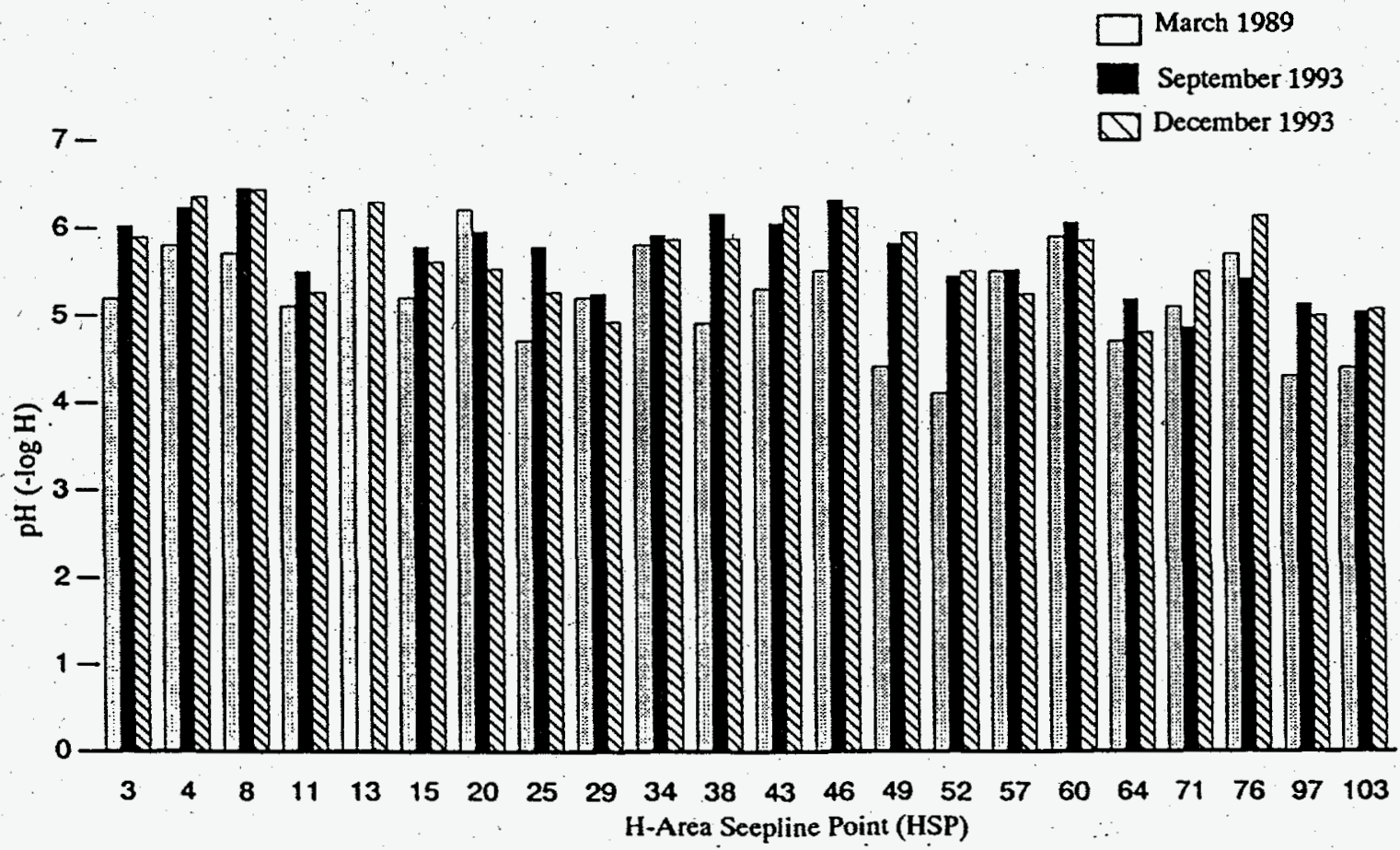

Figure 12. Comparison of March 1989 and September and December $1993 \mathrm{pH}$ Measurements for Selected H-Area Seepline Locations. 

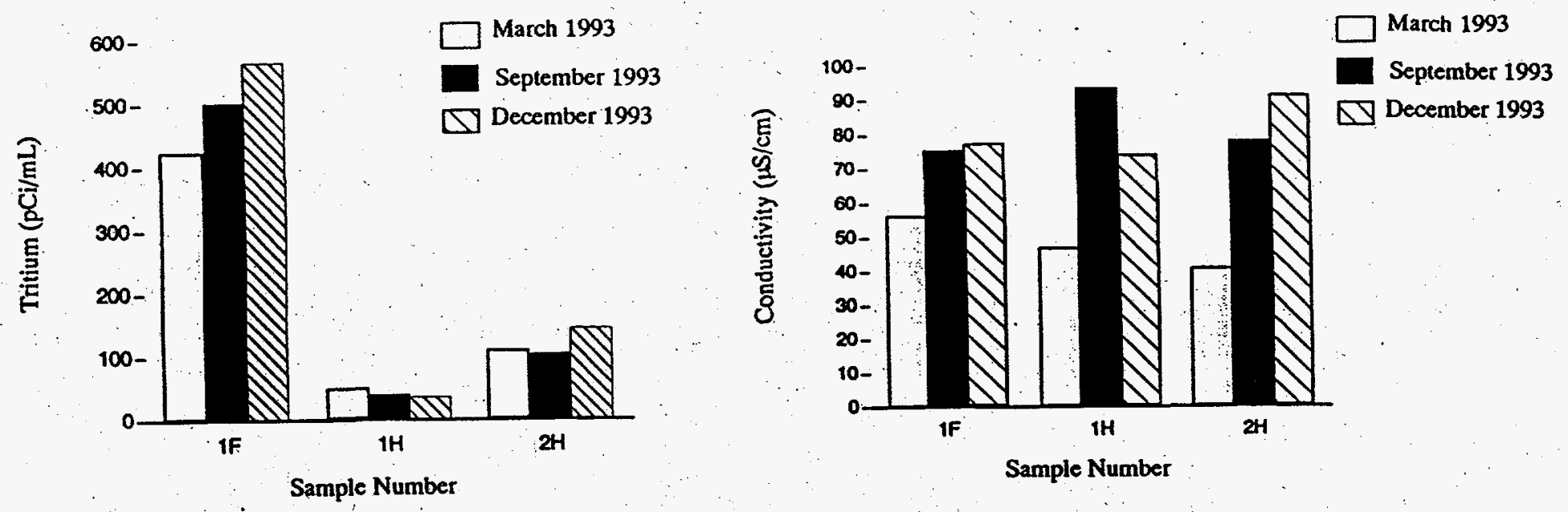

Figure 13. March, September, and December 1993 Tritium Measurements for Selected Stream

Figure 14. March, September, and December 1993 Locations along Fourmile Branch. Conductivity Measurements for Selected Stream Locations along Fourmile Branch.

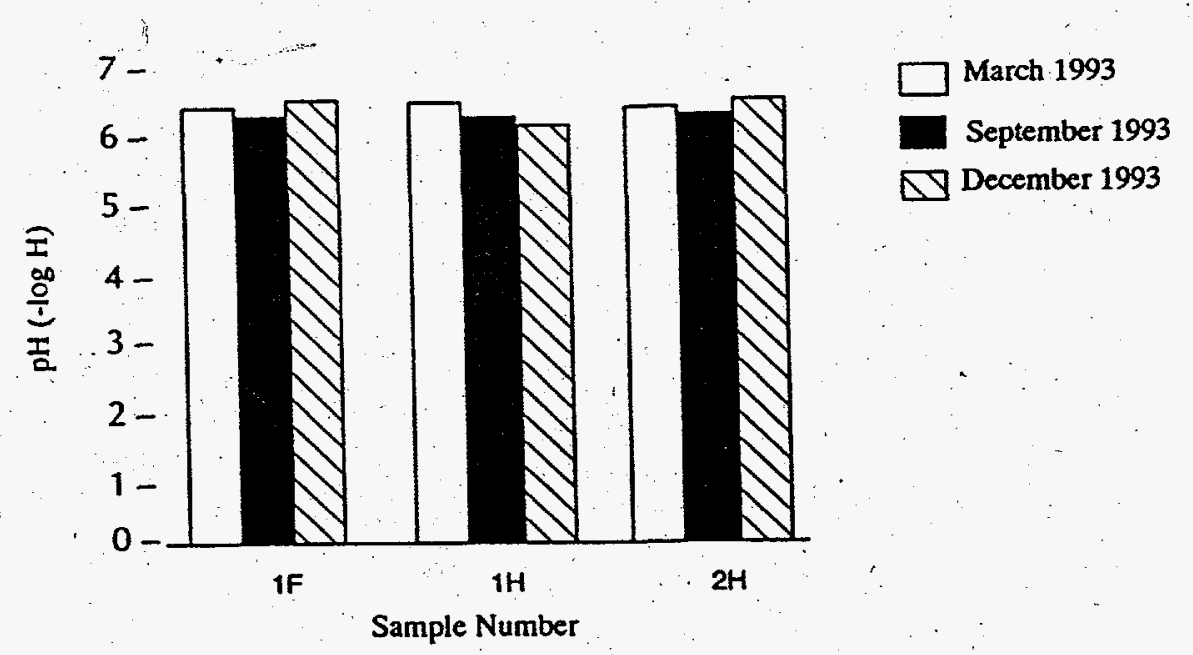

Figure 15. March, September, and December 1993

$\mathrm{pH}$ Measurements for Selected Stream

Locations along Fourmile Branch. 


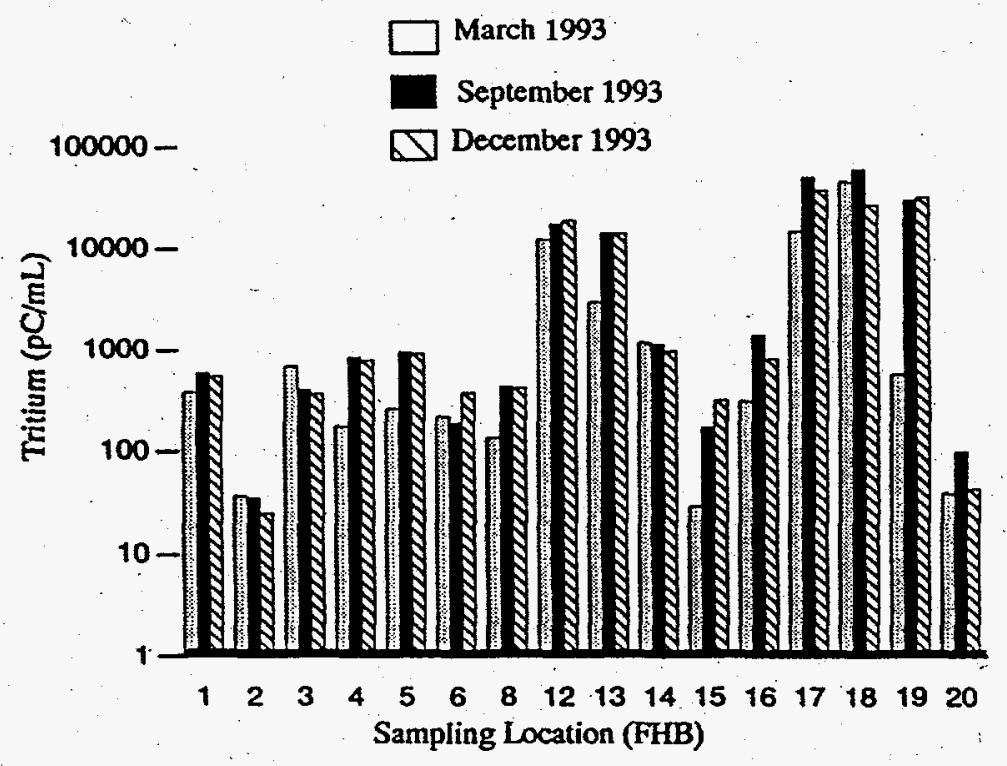

$\therefore \quad$ Figure 16. Comparison of March, September, and December 1993 Tritium Concentrations for Selected Locations on the Seepline South of 643-E.

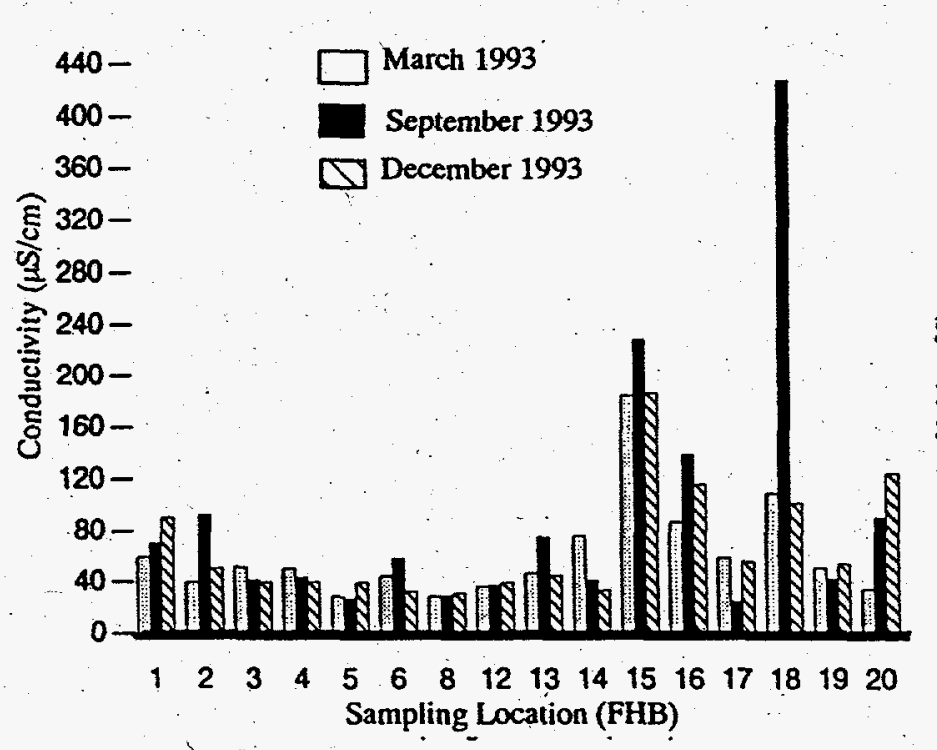

Figure 17. Comparison of March, September, and December 1993 Conductivity Measurements for Selected Locations on the Seepline South of 643-E.



Figure 18. Comparison of March, September, and December $1993 \mathrm{pH}$ Measurements for Selected Locations on the Seepline South of 643-E. 


\section{Tables}

Table 1. Comparison of 1993 Rainfall Totals to the Long-Term Average for F-Area Weather Station (January-November)

\begin{tabular}{lcc} 
Months & $\begin{array}{c}\text { 1993 Rain } \\
(\mathbf{c m})\end{array}$ & $\begin{array}{c}\text { Long-Term Rain } \\
(\mathbf{c m})\end{array}$ \\
\hline January & 22.6 & 11.8 \\
February & 12.9 & 10.8 \\
March & 21.5 & 13.3 \\
April & 3.5 & 8.6 \\
May & 4.0 & 10.7 \\
June & 15.3 & 10.9 \\
July & 7.3 & 12.9 \\
August & 8.8 & 14.3 \\
September & 16.7 & 9.5 \\
October & 1.6 & 5.7 \\
November & 5.8 & 6.6
\end{tabular}

Table 2. Comparison of F-Area Seepline Measurements of Tritium, Conductivity, and pH in March 1989 and September and December 1993.

\begin{tabular}{|c|c|c|c|c|c|c|c|c|c|}
\hline \multirow[b]{2}{*}{ Location } & \multicolumn{3}{|c|}{ Tritium (pCi/mL) } & \multicolumn{3}{|c|}{ Conductivity $(\mu \mathrm{S} / \mathrm{cm})$} & \multicolumn{3}{|c|}{ pH $(-\log H)$} \\
\hline & Mar 89 & Sept 93 & Dec 93 & Mar 89 & Sept 93 & Dec 93 & Mar 89 & Sept 93 & Dec 93 \\
\hline 2 & 520 & 709 & 579 & 94 & 132 & 169 & $5 . \overline{6}$ & 5.6 & 6.2 \\
\hline 7 & 3400 & 667 & 1460 & 681 & 254 & 199 & 5.4 & 5.8 & 5.9 \\
\hline 12 & 260 & 91 & 92 & 30 & 108 & 133 & 5.3 & 5.7 & 5.8 \\
\hline 14 & 14000 & 134 & 15 & 666 & 32 & 27 & 4.2 & 4.5 & 5.1 \\
\hline 19 & 4900 & 3710 & 4237 & 1424 & 917. & 1138 & 4.2 & 3.6 & 3.7 \\
\hline 26 & 4400 & 2020 & 4019 & 1095 & 771 & .1135 & 6.5 & 6.0 & 6.3 \\
\hline 32. & 3600 & 61 & 53 & 174 & 38 & 40 & 5.0 & 4.9 & 5.2 \\
\hline 34 & 14000 & 5720 & 3884 & 810 & 1130 & 803 & 3.8 & 3.6 & 3.7 \\
\hline 35 & 11000 & 17800 & 10436 & 1100 & 1948 & 1511 & 3.9 & 3.6 & 3.7 \\
\hline 40 & 7800 & 8240 & 7434 & 900 & 898 & 1650 & 5.2 & 4.1 & 4.1 \\
\hline 47 & 100 & 38 & 23 & 52 & 45 & 77 & 4.7 & 4.8 . & 5.6 \\
\hline 56 & 19 & 12 & 13 & 34 & 51 & 54 & 4.5 & 5.1 & 5.3 \\
\hline 204 & 3000 & 2400 & 2623 & 895 & 695 & 650 & 4.4 & 4.7 & 4.2 \\
\hline 213 & 2800 & 4140 & 3580 & 860 & 715 & 694 & 4.6 & 4.2 & 4.0 \\
\hline 220 & 560 & 755 & 989 & 147 & 170 & 162 & 4.8 & 5.7 & 5.8 \\
\hline 226 & 1300 & 820 & 967 & 306 & 154 & 234 & 5.1 & 5.4 & 5.7 \\
\hline 235 & 580 & Dry & 529 & 84 & Dry & 107 & 5.7 & Dry . & 5.9 \\
\hline 241 & 560 & 583 & 496 & 36 & 245 & 92 & 4.7 & 5.9 & 5.4 \\
\hline 249 & 580 & 320 & 297 & 84 & 86 & 87 & 4.4 & 5.3 & 5.4 \\
\hline 256 & 400 & 736 & 397 & 56 & 179 & 94 & 5.1 & 5.7 & 5.9 \\
\hline 270 & 40 & 49 & 63 & 50 & 65 & 30 & 4.1 & 5.1 & 4.6 \\
\hline 290 & 35 & 55 & 48 & 49 & 39 & 47 & 3.6 & 5.6 & 5.3 \\
\hline
\end{tabular}


Table 3. Comparison of H-Area Seepline Measurements of Tritium, Conductivity, and pH in March 1989 and September and December 1993.

\begin{tabular}{c|ccc|ccc|ccc} 
& \multicolumn{3}{|c}{ Tritium (pCi/mL) } & \multicolumn{3}{c}{ Conductivity $(\mu \mathrm{S} / \mathrm{cm})$} & \multicolumn{3}{c}{ pH (- log H) } \\
Location & Mar 89 & Sept 93 & Dec 93 & Mar 89 & Sept 93 & Dec 93 & Mar 89 & Sept 93 & Dec 93 \\
\hline 3 & 14000 & 3380 & 6050 & 468 & 216 & 259 & 5.2 & 6.0 & 5.9 \\
4 & 11000 & 3060 & 1570 & 292 & 325 & 166 & 5.8 & 6.2 & 6.4 \\
8 & 24000 & 4440 & 3730 & 556 & 267 & 213 & 5.7 & 6.5 & 6.4 \\
11 & 960 & 123 & 116 & 80 & 65 & 67 & 5.1 & 5.5 & 5.3 \\
13 & 12000 & Dry & 1055 & 592 & Dry & 191 & 6.2 & Dry & 6.3 \\
15 & 1000 & 371 & 1250 & 82 & 270 & 160 & 5.2 & 5.8 & 5.6 \\
20 & 6500 & 1190 & 971 & 183 & 143 & 109 & 6.2 & 6.0 & 5.5 \\
25 & 3300 & 5120 & 3119 & 135 & 128 & 107 & 4.7 & 5.8 & 5.3 \\
29 & 9200 & 510 & 597 & 257 & 116 & 119 & 5.2 & 5.3 & 4.9 \\
34 & 5600 & 1990 & 1058 & 331 & 226 & 163 & 5.8 & 5.9 & 5.9 \\
38 & 6500 & 307 & 465 & 227 & 228 & 98 & 4.9 & 6.2 & 5.9 \\
43 & 10000 & 4680 & 4213 & 413 & 399 & 323 & 5.3 & 6.1 & 6.2 \\
46 & 11000 & 3120 & 5459 & 318 & 155 & 257 & 5.5 & 6.3 & 6.2 \\
49 & 11000 & 5850 & 3536 & 551 & 200 & 170 & 4.4 & 5.8 & 5.9 \\
52 & 20000 & 15500 & 12688 & 699 & 685 & 612 & 4.1 & 5.5 & 5.5 \\
57 & 15000 & 3250 & 4434 & 581 & 203 & 256 & 5.5 & 5.5 & 5.2 \\
60 & 21000 & 3050 & 3901 & 473 & 167 & 188 & 5.9 & 6.1 & 5.9 \\
64 & 320 & 124 & 179 & 38 & 85 & 56 & 4.7 & 5.2 & 4.8 \\
71 & 450 & 852 & 479 & 40 & 65 & 52 & 5.1 & 4.9 & 5.5 \\
76 & 400 & 344 & 768 & 146 & 79 & 150 & 5.1 & 5.4 & 6.1 \\
97 & 1100 & 4020 & 3617 & 37 & 238 & 210 & 4.3 & 5.2 & 5.0 \\
103 & 510 & 1420 & 1218 & 43 & 75 & 53 & 4.4 & 5.1 & 5.1
\end{tabular}

Table 4. Comparison of Fourmile Branch Stream Measurements of Tritium, Conductivity, and pH in March, September, and December 1993.

\begin{tabular}{l|ccc|ccc|ccc} 
& \multicolumn{3}{|c|}{ Tritium (pCi/mL) } & \multicolumn{3}{|c|}{$\begin{array}{c}\text { Conductivity } \\
(\mu \mathrm{S} / \mathrm{cm})\end{array}$} & \multicolumn{3}{c}{ pH (-log H) } \\
Location & Mar 93 & Sept 93 & Dec 93 & Mar 93 & Sept 93 & Dec93 & Mar 93 & Sept 93 & Dec 93 \\
\hline $1 \mathrm{~F}$ & 425 & 503 & 567 & 56 & 75 & 77 & 6.3 & 6.2 & 6.5 \\
$1 \mathrm{H}$ & 47 & 41 & 37 & 46 & 93 & 74 & 6.4 & 6.2 & 6.1 \\
$2 \mathrm{H}$ & 104 & 105 & 145 & 40 & 77 & 91 & 6.3 & 6.2 & 6.4
\end{tabular}


Table 5. Comparison of Seepline Below 643-E Measurements of Tritium, Conductivity, and pH in March, September and December 1993.

\begin{tabular}{crrr|rrr|rrr} 
& \multicolumn{3}{c}{ Tritium (pCl/mL) } & \multicolumn{3}{c|}{ Conductivity $(\mu \mathrm{S} / \mathbf{c m})$} & \multicolumn{3}{c}{ pH (- log H) } \\
Location & Mar 93 & Sept 93 & Dec 93 & Mar 93 & Sept 93 & Dec 93 & Mar 93 & Sept 93 & Dec 93 \\
\hline 1 & 387 & 598 & 553 & 60 & 71 & 91 & 5.8 & 5.7 & 5.35 \\
2 & 37 & 35 & 25 & 40 & 93 & 51 & 5.2 & 5.5 & 4.97 \\
3 & 682 & 408 & 370 & 52 & 42 & 40 & 5.7 & 5.2 & 5.32 \\
4 & 175 & 853 & 785 & 51 & 44 & 40 & 4.8 & 5.2 & 5.05 \\
5 & 263 & 947 & 907 & 29 & 27 & 40 & 5.4 & 5.4 & 5.03 \\
6 & 217 & 190 & 378 & 45 & 59 & 33 & 5.5 & 4.9 & 5.07 \\
8 & 134 & 432 & 419 & 29 & 30 & 32 & 5.2 & 4.8 & 4.52 \\
12 & 12000 & 17100 & 18738 & 37 & 30 & 40 & 5.4 & 5.2 & 5.03 \\
13 & 2860 & 13800 & 13762 & 47 & 76 & 34 & 5.1 & 5.5 & 5.32 \\
14 & 1150 & 1090 & 939 & 77 & 42 & 187 & 5.3 & 5.2 & 4.92 \\
15 & 29 & 169 & 315 & 185 & 229 & 117 & 6.0 & 6.3 & 5.68 \\
16 & 306 & 1360 & 785 & 88 & 140 & 57 & 6.2 & 5.3 & 5.33 \\
17 & 14100 & 49200 & 36383 & 60 & 25 & 102 & 5.5 & 5.2 & 5.21 \\
18 & 44000 & 59400 & 25966 & 110 & 428 & 55 & 5.6 & 6.7 & 5.33 \\
19 & 546 & 29100 & 30537 & 52 & 43 & 125 & 4.4 & 5.0 & 4.13 \\
20 & 38 & 95 & 42 & 35 & 91 & 40 & 5.0 & 5.9 & 5.83
\end{tabular}

\footnotetext{
*Stream Sample Location
} 